\author{
이 호* \\ 경기대학교 식품생물공학과
}

\title{
Immuno-stimulating Activities of Mannose-rich Polysaccharides Isolated from Korean Black Raspberry Wine
}

\author{
Ho Lee* \\ Department of Food Science \& Biotechnology, Kyonggi University
}

\begin{abstract}
Polysaccharides isolated from Korean black raspberry wine were examined for their chemical properties and immuno-modulating activities. The molecular mass of RB-1b-I, the main polysaccharide in black raspberry wine, was estimated as $180 \mathrm{kDa}$ and it contained a significant proportion of mannose (76.8\%) and 4 different minor component sugars such as galactose $(15.8 \%)$, arabinose $(3.8 \%)$, glucose $(2.6 \%)$ and rhamnose $(1.2 \%)$. This indicated that RB- $1 \mathrm{~b}-\mathrm{I}$ was mainly present as a mannan, which had originated from the cell walls of fermenting yeasts. On the other hand, RB-1b-I induced high levels of macrophage activation as well as mitogenicity regarding murine splenocytes in vitro. The intravenous administration of RB-1b-I significantly augmented NK cytotoxicity against YAC-1 tumor cells. RB-1b-I also showed potent anti-complementary activity in a dose-dependent manner via both alternative and classical pathways. Results indicated that Korean black raspberry wine contains peculiar polysaccharides which provide beneficial immuno-stimulating activities for human health.
\end{abstract}

Keywords: raspberry wine, polysaccharide, mannan, immuno-stimulating activity

\section{서 론}

과실주로 대표되는 저 알코올 주류의 적절한 음용은 심혈관계 질환의 예방 및 개선에 효과가 있다고 보고(1,2)되고 있어 최근 그 수요가 크게 증가하고 있다. 특히 적포도주의 경우, flavonoid 를 비롯한 다양한 polyphenol( 3,4$)$ 이 존재하고 이들이 갖는 항산 화 효과 $(5,6)$ 때문에 건강에 유익한 것으로 알려져 있으며 항염 증작용, 항고혈압작용, 항응고작용 및 저밀도 지방단백(LDL)의 산화 억제 등 다양한 기능들이 보고되고 있어 관심과 연구가 집 중되고 있다(4). 그러나 전통발효음료에서 기대되는 모든 약리활 성이 단지 polyphenol만의 기능이라고는 할 수 없으며, 생리활성 을 갖는 타 화합물의 존재 가능성이 있을 수 있다. 발효주의 원 료가 되는 생과에는 저분자 및 고분자의 다양한 생리활성 물질 이 존재할 것으로 기대되고 있으며 특히 이들을 발효한 발효주 의 경우, 발효과정 동안 화학적 변화에 의해 원료에는 함유되어 있지 않은 미지의 물질과 생리활성을 가지는 물질을 함유할 가 능성이 높다고 할 수 있다. 일반적으로 다당은 고농도의 알코올 용액에서 침전되는 성질 때문에 그동안 발효주 중의 활성성분으 로 주목받지 못하였지만, 비교적 낮은 알코올 농도(10-12\%)에서

*Corresponding author: Ho Lee, Dept. of Food Science and Biotechnology, Kyonggi University, Suwon, Gyeonggi 443-760, Korea

Tel: 82-31-249-9653

Fax: 82-31-249-9650

E-mail: hlee@kyonggi.ac.kr

Received February 4, 2012; revised March 6, 2012;

accepted March 6, 2012
선택적으로 용해되어 존재할 가능성이 여전히 남아있다고 할 수 있다.

복분자(Rubus coreanus Miquel)는 주로 우리나라의 남부지방에 서 야생 또는 재배되고 있는 대표적 과실 중 하나로 일본 및 중 국에서도 다량 생산되고 있다. 복분자는 생과 또는 냉동과 형태 로 소비되거나 주스, 잼 및 아이스크림 형태로 가공되는데 많은 부분은 복분자주 형태로 발효되어 음용되고 있다(7). 복분자에는 anthocyanin, flavonoid, tannin, stilbenoids, phenolic acid 및 lignan과 같은 다양한 phytochemical을 다량 함유 $(8,9)$ 하고 있어 높 은 항산화 활성이 보고되고 있다 $(10,11)$. 최근에는 인간 유래의 다양한 종양 세포주(대장암; HT-29, HCT116, 구강암; KB, CAL27 유방암; MCF-7, 전립선암; $\mathrm{LNCaP}$ )에 대한 복분자의 증식억제 능(12)이 보고된 바 있으며, 복분자 추출물이 갖는 cyclooxygenase2 및 nitric oxide synthase 발현 저해능이 보고(13)되기도 하였다. 한편 Jung 등(14)은 수입 적포도주에 상당하는 높은 항산화활성 이 복분자주에 존재하며 인간 선암(adenocarcinoma) 및 간모세포 종(hepatoblastoma)에 대한 높은 항암활성을 보고하기도 하였다. 그러나 이러한 복분자 유래의 다양한 생물활성에 대한 연구는 대 부분 저분자의 phytochemical류에 집중되어 있으며, 복분자주에 대한 연구도 주로 발효 특성(15) 및 성분분석 연구(16)가 대부분 으로 생리기능성의 과학적 해명, 특히 복분자주 유래 다당의 기 능성에 대한 연구는 전무한 실정이다.

따라서 본 연구에서는 우리나라 특산의 복분자주를 대상으로 다당을 분리, 정제하고 이들의 화학적 특성을 검토하였으며, 각 종 면역자극활성을 평가함으로써 전통발효주의 새로운 기능성 해 명에 대한 기초자료를 제공하고자 하였다. 


\section{재료 및 방법}

\section{재료}

본 실험에 사용한 복분자주(raspberry wine)는 2009년 6월 전북 고창군 농가에서 채취하여 지역 농가의 전통방법에 따라 발효하 고 약 1 년간 숙성된 제품을 사용하였다. 사용된 복분자주는 알코 올함량 약 $11.5 \%$ 로 제공받은 즉시 Whatman No. 1(Maidstone, $\mathrm{UK}$ )필터로 여과하고 회전 감압농축장치(Eyela, Tokyo Rikakikai Co., Tokyo, Japan)를 이용 1/5 부피로 농축하고 실험에 사용하였다.

\section{일반 분석방법}

중성당 함량은 galactose를 표준물질로 하여 phenol-sulfuric acid 법(17)으로, 산성당 함량은 galacturonic acid를 표준물질로 하여 $m$-hydroxydiphenyl법(18)으로, 단백질 함량은 표준물질로 bovine serum albumin을 사용하여 Bradford법(19)으로 측정하였다. 한편 분자량 및 정제도 측정에 사용한 HPLC는 Asahipak GS-520+GS$320+\mathrm{GS}-220$ (각 $0.5 \times 30 \mathrm{~cm}$, Showa Denko Co., Tokyo, Japan)을 장착한 HPLC-9500(Young-Lin Co. Ltd., Anyang, Korea)를 사용 하여 $0.2 \mathrm{M} \mathrm{NaCl}$ 를 용매로 $0.5 \mathrm{~mL} / \mathrm{min}$ 로 용출하였으며, refractive index detector(Waters, Milford, MA, USA)로 검출하였다. 정제다 당의 분자량은 standard pullulans(P-800, P- $400,200,100,50,20$, 10 및 5; Showa Denko Co.)를 표준물질로 하여 얻어진 표준곡선 과 비교하여 측정하였다. 구성당 분석은 다당시료를 $2 \mathrm{M}$ trifluoroacetic acid(TFA)로 $121^{\circ} \mathrm{C}$ 에서 1.5 시간 가수분해한 후, 각각 alditol acetate 유도체(20)로 전환시킨 후, $\mathrm{GC}$ 로 분석하였다. $\mathrm{GC}$ 의 분 석은 SP-2380 capillary column $(0.2 \mu \mathrm{m}$ film, $0.25 \mathrm{~mm}$ i.d. $\times 30 \mathrm{~m}$, Supelco, Bellefonte, PA, USA)이 장착된 $\mathrm{GC}$ M600D(Young-Lin Co. Ltd.)를 이용하였으며 표준 온도조건 $\left(60^{\circ} \mathrm{C}(1 \mathrm{~min}), 60 \rightarrow 220^{\circ} \mathrm{C}\right.$ $\left.\left(30^{\circ} \mathrm{C} / \mathrm{min}\right), 220^{\circ} \mathrm{C}(12 \mathrm{~min}), 220 \rightarrow 50^{\circ} \mathrm{C}\left(8^{\circ} \mathrm{C} / \mathrm{min}\right), 250^{\circ} \mathrm{C}(15 \mathrm{~min})\right)$ 에 서 분석을 실시하였다. 구성당의 mole \%는 peak의 면적비, flame ionization detector(FID)에 대한 반응계수 및 각 구성당의 alditol acetate 유도체의 분자량으로부터 계산하였다.

\section{면역활성다당의 분리 및 정제}

복분자주를 회전 감압농축장치(Eyela Co., Tokyo, Japan)를 이 용하여 5 배 농축하고 최종농도가 $80 \%$ 가 되도록 에탄올을 첨가 하여 하룻밤 방치한 후, 발생한 침전물을 회수하고 $80 \%$ 에탄올 을 이용, 적색색소가 제거될 때 까지 수차례 세척하였다. 침전물 은 소량의 증류수에 용해하여 Spectra/Por 2 투석막(MWCO; 12,000-14,000, Spectrum Laboratories Inc., Rancho Dominguez, $\mathrm{CA}, \mathrm{USA}$ )을 이용하여 2-3일간 투석을 행하고 동결건조를 행하 여 조다당 시료인 RB- 0 를 얻었다. 조다당 RB- 0 는 $50 \mathrm{mM}$ acetate $\operatorname{buffer}(\mathrm{pH}$ 5.2)로 평형화된 Sephadex G-75 column $(2.5 \times 90 \mathrm{~cm}$, Amersham Bio-sciences, Uppsala, Sweden))에 loading하고 동일 buffer를 이용하여 용출시켜 분자량이 상이한 2개 획분, RB-1 및 $\mathrm{RB}-2$ 로 분획하였다. 이 중 활성이 양호한 고분자 획분인 RB-1은 증류수로 평형화된 $\mathrm{DEAE}-S$ epharose $\mathrm{FF}\left(\mathrm{Cl}^{-}\right.$form, $2.5 \times 25 \mathrm{~cm}$, Amersham Bio-sciences)에 흡착시킨 후 증류수, $0.1,0.2$ 및 $0.3 \mathrm{M}$ 의 $\mathrm{NaCl}$ 용액으로 단계적으로 용출시켰으며, 이때 활성과 수율이 우수했던 $\mathrm{RB}-1 \mathrm{~b}$ 획분 $(0.1 \mathrm{M} \mathrm{NaCl}$ 용출)을 이후의 정제과정에 사용 하였다. RB-1b 획분은 $50 \mathrm{mM}$ acetate buffer(pH 5.2)로 평형화된 Biogel P-100 column $(2.5 \times 100 \mathrm{~cm}$, Bio-Rad Laboratories, Hercules, $\mathrm{CA}, \mathrm{USA}$ )을 이용, 겔여과를 행하여 최종 활성획분인 정제 RB-1b-I을 얻었다(Fig. 1).

\section{비장세포 mitogen 활성능 측정}

ICR mouse(6-8주령, 웅성, Koatec Co., Seoul, Korea)에서 비장 을 적출하여 마쇄 및 여과를 거쳐 비장세포를 획득한 후, $0.2 \%$ 식염수를 이용 적혈구를 제거하고, RPMI 1640-FBS 배지(7\% fetal bovine serum 함유 RPMI 배지, Gibco BRL Co., NY, USA)로 $2-3$ 회 세척하여 세포수를 $5 \times 10^{6} \mathrm{cell} / \mathrm{mL}$ 가 되도록 조정하였다. 이 때 얻어진 세포 부유액은 96 well plate에 $90 \mu \mathrm{L}$ 씩 분주하고 10 $\mu \mathrm{L}$ 의 시료용액을 첨가하여 $37^{\circ} \mathrm{C}, 5 \% \mathrm{CO}_{2}$ incubator에서 72 시간 배양한 후, 각 well당 $10 \mu \mathrm{L}$ 의 CCK-8 kit(Dojindo Laboratories, Kumamoto, Japan) 용액을 첨가하여 $37^{\circ} \mathrm{C}, 5 \% \mathrm{CO}_{2}$ incubator에서 3 시간 배양하고 $450 \mathrm{~nm}$ 에서 흡광도를 측정하여 활성을 비교하였다.

\section{Macrophage 활성화능 측정}

Macrophage 활성능 측정은 Suzuki 등(21)의 방법을 실험실 여 건에 맞게 변형하여 사용하였다. 즉, $\mathrm{BALB} / \mathrm{c}$ mouse(웅성, 6-8주 령, Koatec Co.)의 복강에 $5 \%$ thioglycollate 배지(Sigma Chemical Co., St. Louis, MO, USA)를 $2 \mathrm{~mL}$ 주입하고 72-96시간 내에 유도된 macrophage를 회수한 후, RPMI 1640(Gibco BRL Co.)으 로 2-3회 세척하고 세포수를 $1 \times 10^{6} \mathrm{cell} / \mathrm{mL}$ 로 조정하여 96 well plate에 $100 \mu \mathrm{L}$ 씩 분주하였다. 이를 $5 \% \mathrm{CO}_{2}$ incubator에서 배양 $\left(37^{\circ} \mathrm{C}, 2 \mathrm{~h}\right)$ 하여 macrophage monolayer를 형성시키고 상등액을 제 거한 후, 미부착 macrophage RPMI 1640-FBS 배지(Gibco BRL $\mathrm{Co}$.)를 이용하여 세척하였다. 여기에 RPMI 1640-FBS을 각 well 당 $180 \mu \mathrm{L}$ 를 분주하고, $20 \mu \mathrm{L}$ 의 시료를 첨가하여 $37^{\circ} \mathrm{C}, 5 \% \mathrm{CO}_{2}$ incubator에서 24시간 배양하였다. 배양 후 활성화된 macrophage monolayer를 배지로 세척하고, $1 \%$ Triton X-100(Sigma) $25 \mu \mathrm{L}$ 씩 을 가하여 세포막을 용해한 후, macrophage로부터 유리된 lysosomal phosphatase를 기질인 $p$-NPP(p-nitrophenylphosphate, $1 \mathrm{mg}$ / $\mathrm{mL}$ of $0.025 \mathrm{M}$ citrate buffer, $\mathrm{pH} 5.0$, Sigma) $200 \mu \mathrm{L}$ 와 반응시 킨 다음 microplate reader(Molecular Devices, Sunnyvale, CA, USA)를 이용하여 $405 \mathrm{~nm}$ 에서 흡광도를 측정하였다.

\section{자연치사세포(NK cell)의 살해능 측정}

복분자주에서 정제한 다당 물질을 6-8주령의 웅성 $\mathrm{BALB} / \mathrm{c}$ 마 우스에 정맥주사하고 3 일 후에 비장을 적출하여 비장세포를 조 제하였다. 96-well plate에 마우스로부터 얻은 비장세포(effector cell, E)와 NK cell 감수성으로 알려진 종양세포 YAC-1(target cell, $\mathrm{T})$ 을, $\mathrm{E} / \mathrm{T}$ 비율이 $100: 1,50: 1,25: 1,12.5: 1$ 이 되도록 조정하여 6 시간 동안 배양하였다. 이때 비장의 NK cell의 살해능에 의해 표 적세포로부터 유리되는 lactate dehydrogenase $(\mathrm{LDH})$ 의 발생량을 CytoTox 96 kit(Promega, San Luis Obispo, CA, USA)을 사용하 여 측정하였다. $\mathrm{NK}$ cell의 종양세포 살해능은 다음 식에 의해 계 산하였다(22). Cytotoxicity $(\%)=(($ experimental LDH release-spontaneous $\mathrm{LDH}$ release)/(maximum LDH release-spontaneous LDH release) $) \times 100$.

\section{보체계 활성화능}

항보체 활성은 Mayer법(23)을 이용하여 시료에 의한 보체 활 성화 후, 잔존하는 보체에 의한 적혈구 용혈활성에 근거를 둔 complement fixation test로 측정하였다. 즉 정상인의 혈청과 $2 \%$ gelatin, $3 \mathrm{mM} \mathrm{Ca}^{2+}, 10 \mathrm{mM} \mathrm{Mg}$ 이 함유된 $\mathrm{GVB}^{2+}$ 완충용액(gelatin veronal buffered saline, $\mathrm{pH}$ 7.4) 및 시료를 각각 $50 \mu \mathrm{L}$ 씩 혼 합하여 $37^{\circ} \mathrm{C}$ 에서 30 분 동안 1 차 반응시킨 후, 이 반응액에 $\mathrm{GVB}^{2+}$ 를 $350 \mu \mathrm{L}$ 씩 첨가하고 이를 10-160배까지 연속 희석하였다. 여기 
에 $750 \mu \mathrm{L}$ 의 $\mathrm{GVB}^{2+}$ 와 양의 감작적혈구(IgM-sensitized sheep erythrocytes, EA Cell, Biotest Co. Tokyo, Japan)를 $250 \mu \mathrm{L}$ 씩 가 하여 $37^{\circ} \mathrm{C}$ 에서 1 시간 반응시키고, $4^{\circ} \mathrm{C}$ 의 $\mathrm{PBS}$ (phophate buffered saline)를 $2.5 \mathrm{~mL}$ 가하여 반응을 정지시켰다. 각 반응액을 $4^{\circ} \mathrm{C}$, $2,500 \mathrm{rpm}$ 에서 10 분간 원심분리 하였으며 상등액의 흡광도를 $412 \mathrm{~nm}$ 에서 측정하였다. 항보체 활성은 총보체 용혈 저지율 (Inhibition of $50 \%$ total complement hemolysis, $\mathrm{ITCH}_{50}$ )로 나타 내었다.

\section{2차원 면역전기영동(Crossed Immunoelectrophoresis)}

$\mathrm{GVB}^{2+}$ buffer, $10 \mathrm{mM}$ EDTA가 함유된 EDTA-GVB ${ }^{2-}$ buffer, 2 $\mathrm{mM} \mathrm{MgCl}_{2}$ 및 $10 \mathrm{mM}$ ethylene glycol-bis(2-aminoethylether)$\mathrm{N}, \mathrm{N}, \mathrm{N}^{\prime}, \mathrm{N}^{\prime}$-tetraacetic acid(EGTA)가 함유된 $\mathrm{Mg}^{2+}$-EGTA-GVB ${ }^{2-}$ buffer에 정상인의 혈청과 시료를 각각 혼합하여 $37^{\circ} \mathrm{C}, 30$ 분간 반 응시킨 후, $\mathrm{pH} 8.6$ barbital buffer(ionic strength, 0.025)를 사용하 여 조제한 $1 \%$ agarose gel 상에서 1차원 전기영동을 행하였다(3 $\mathrm{mA} / \mathrm{cm}$ ). 이후 $0.5 \%$ anti-human $\mathrm{C} 3$ serum(Sigma-Aldrich Chemical Co., St. Louis, MO, USA)이 함유된 1\% agarose gel 상에서 약 15 시간 동안 2 차 전기영동을 행하였다 $(1 \mathrm{~mA} / \mathrm{cm})$. 전개된 gel 은 bromophenol blue로 염색시켜 항체와 반응하여 형성된 침강선 을 관찰함으로써 $\mathrm{C} 3$ 의 분해 산물을 확인하였다(24).

\section{보체계 활성의 측정}

보체계 활성화 경로를 조사하기 위해 $\mathrm{GVB}^{2+}$ 와 $\mathrm{GVB}^{2+}$ 에서 $\mathrm{Ca}^{2+}$ 이온만을 제거한 $\mathrm{Mg}^{2+}-\mathrm{EGTA}-\mathrm{GVB}^{2-}$ 및 금속이온을 모두 제거한 $\mathrm{EDTA}-\mathrm{GVB}^{2-}$ buffer에 시료 및 정상인의 혈청을 각각 첨가하고 상기 방법과 같이 총보체 용혈의 저지율을 측정함으로써 시료의 보체계 활성화 경로를 비교 검토하였다.

\section{통계처리}

실험결과는 평균값 \pm 표준오차(mean \pm standard deviation)로 나타 내었고 Student $t$-test를 이용하여 통계처리한 후 $p<0.01$ 수준에서 유의성을 검정하였다.

\section{결과 및 고찰}

\section{복분자주로부터 다당의 분리 및 정제}

전북지역 농가에서 2010년 발효 생산한 복분자주를 5배 감압 농축하고 에탄올 침전과 투석 및 동결건조를 행하여 조다당 RB0 를 얻었다. 수율은 복분자주 $\mathrm{L}$ 당 총 $1.65 \mathrm{~g}$ 으로, 복분자주에는 비교적 많은 양의 수용성 다당이 존재함을 알 수 있었다. 복분자 에서 분리된 수용성 다당 RB-0은 Sephadex G-75를 이용한 겔여 과를 행하여 분자량이 상이한 RB-1 및 RB-2 2개 획분으로 분리 되었다(Fig. 1). RB-1과 RB-2 획분은 조다당 RB-0 대비 각각 $51 \%$ 와 $19 \%$ 의 수율을 보여 RB-1이 상대적으로 높은 비율로 복 분자주에 함유되어 있었다. $100 \mu \mathrm{g} / \mathrm{mL}$ 농도에서 비장세포 mitogen 활성을 기준으로 하였을 때의 면역 활성은 RB-1이 $298 \%$ 로 조다 당 $260 \%$ 보다 우수하였으며, RB-2의 경우는 $250 \%$ 를 나타내어 조다당보다 다소 낮은 활성을 보였다. 수율과 면역활성 측면에서 상대적으로 양호했던 RB-1은 DEAE-Sepharose FF를 이용하여 음 이온 교환 chromatography를 행하여 비흡착 1 개 획분 RB-1a과 $0.1,0.2,0.3 \mathrm{M} \mathrm{NaCl}$ 용액으로 용출되는 3 개의 흡착획분 $\mathrm{RB}-1 \mathrm{~b}$, RB-1c, RB-1d로 분획할 수 있었다. 이들 중 수율은 RB- $1 \mathrm{~b}$ 가 가 장 높았으며 면역활성은 흡착 3 개 획분에서 비흡착 획분(168\%) 보다 우수한 약 $300 \%$ 의 활성을 나타냈으며 흡착 획분간 활성의
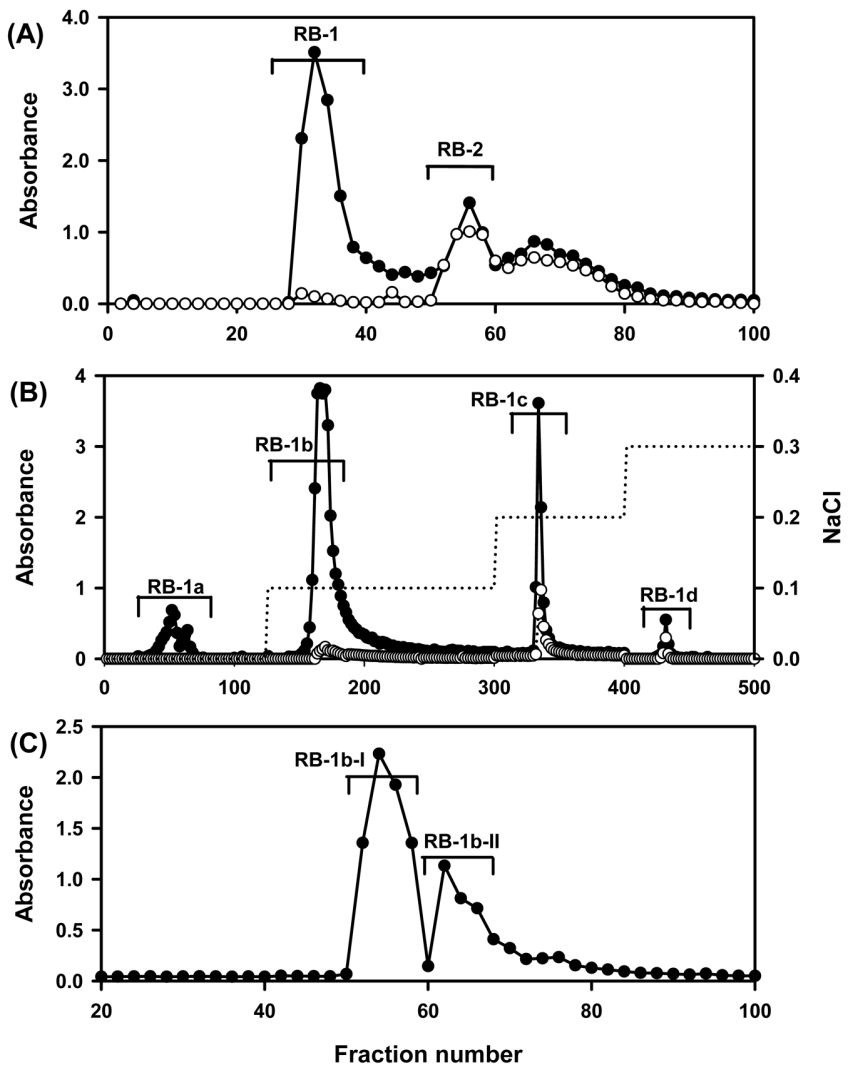

Fig. 1. Column chromatographies for the purification of immuno-stimulating polysaccharide, RB-1b-I from Korean black raspberry wine. (A) The crude polysaccharide (RB-0) was applied to a column $(2.5 \times 90 \mathrm{~cm})$ of Sephadex G-75 and eluted with $50 \mathrm{mM}$ acetate buffer (pH 5.2), (B) RB-1 fraction was rechromatographed on the column $(2.5 \times 25 \mathrm{~cm})$ of DEAE-Sepharose $\mathrm{FF}\left(\mathrm{Cl}^{-}\right.$ form) and eluted with linear concentration gradient $0.0 \rightarrow 0.3 \mathrm{M}$ $\mathrm{NaCl}$, (C) RB-1b fraction was finally loaded to a Biogel P-100 column $(2.5 \times 100 \mathrm{~cm})$ and eluted with $50 \mathrm{mM}$ acetate buffer $(\mathrm{pH}$ 5.2). Neutral sugar (490 nm); $\bigcirc$, Uronic acid $(520 \mathrm{~nm}) ; \cdots \cdot . \cdot \mathrm{NaCl}$.

유의차는 없었다. 따라서 높은 수율과 활성을 보였던 RB- $1 b$ 는 Biogel P- 100 를 이용하여 다시 겔여과를 행하였다. RB- $1 \mathrm{~b}$ 는 각각 RB-1b-I 및 RB-1b-II로 정제할 수 있었다(Fig. 1). 복분자주에서 정제한 다당, RB-1b-I의 순도 및 분자량을 확인하기 위하여 HPLC 를 행한 결과, RB-1b-I은 대체로 좌우대칭을 유지한 단일 peak를 나타내어 비교적 순수하게 정제되었음을 확인할 수 있었으며, 표 준물질(pullulan series)을 이용한 분자량 측정 결과 분자량이 180 $\mathrm{kDa}$ 의 다당체임을 알 수 있었다(Fig. 2).

\section{복분자주 유래 정제다당의 화학적 특성}

복분자주에서 정제된 다당 RB- $1 \mathrm{~b}-\mathrm{I}$ 의 일반 화학특성을 살펴본 결과는 Table 1과 같다. RB- $1 \mathrm{~b}-\mathrm{I}$ 은 $100 \%$ 중성당만으로 구성되어 있었으며 일반적으로 식물 추출물에서 검출되는 산성당 및 단백 질 등은 함유하고 있지 않았다. 한편 RB-1b-I을 가수분해하여 alditol acetate유도체로 전환하고 구성당을 분석한 결과, RB-1b-I 은 mannose가 $76.8 \%$ 로 주를 이루고 있었으며, 그 외에 galactose (15.8\%), arabinose(3.8\%), glucose $(2.6 \%)$ 및 rhamnose(1.2\%)의 순 으로 함유되어 있었다. 이러한 화학 조성은 단순 식물 추출물에 서는 잘 관찰되지 않는 특이한 당 조성으로, 산성당이 전혀 검출 되지 않은 점과 mannose의 함량이 특히 높은 점 등의 사실로 미 


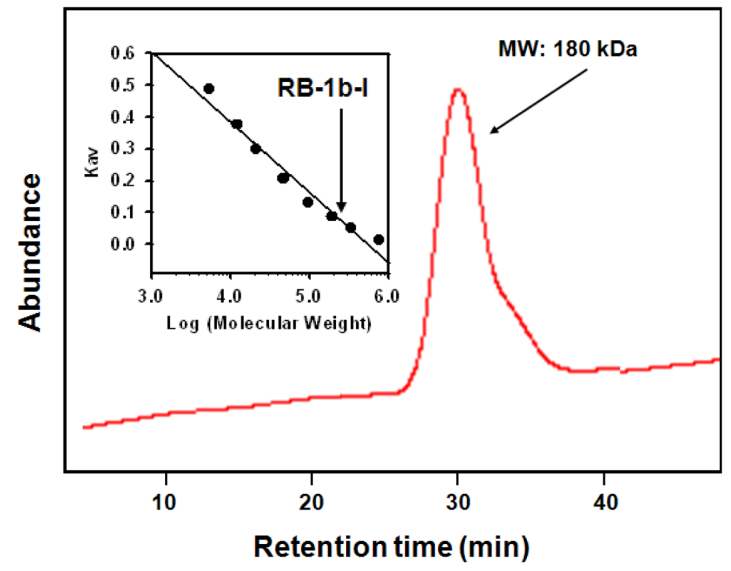

Fig. 2. HPLC profile and molecular weight of the purified polysaccharide, RB-1b-I from Korean black raspberry wine. RB-1b-I was injected into combined columns $(0.5 \times 30 \mathrm{~cm}$, each $)$ of Asahi-pak GS-520+GS-320+GS-220 and then eluted with $0.2 \mathrm{M}$ $\mathrm{NaCl}$ at a flow rate of $0.5 \mathrm{~mL} / \mathrm{min}$.

루어 볼 때, 재료인 복분자의 다당 성분이 발효 및 숙성과정에서 변형되었거나 또는 발효 미생물에 의한 새로운 다당의 혼입 가 능성이 제기되었다.

복분자주의 주 다당 RB-1b-I에서 mannose가 높은 비율로 존재 한다는 사실은 RB-1b-I이 mannan으로 존재할 가능성을 시사하지 만 식물체 특히 과실에서 mannan이 관찰된 경우는 드물며, 특히 세포벽 성분으로 mannan의 존재가 보고된 예는 거의 찾아볼 수 없다. 따라서 RB-1b-I에 존재하는 고 mannose 함량은 발효 중 사 용된 미생물 기원의 mannan에서 유래한 것으로 추정되었다. 복 분자주 발효는 크게 알코올 발효단계와 숙성단계로 나뉘며 알코 올 발효단계에는 Saccharomyces cerevisiae와 같은 효모가 관여하 는데, 동 효모의 세포벽은 $\beta$-glucan 및 chitin이 주성분으로 되어 있으며 세포벽 최외각에는 mannoprotein이 결합되어 있는 것으로 보고(25)되고 있다. 따라서 발효 및 숙성과정 중 알코올 발효를 담당하였던 효모가 자가분해되어 이중 용해도가 낮은 $\beta$-glucan과 chitin은 숙성과정 중 침전하게 되고, 복분자주 중에는 효모 세포 벽 기원의 mannan이 선택적으로 용해됨을 추론할 수 있었다. 한 편 식물체의 대표적 수용성 다당인 펙틴물질(pectic substance)은 고등식물의 1 차 세포벽과 중엽(middle lamella)에 주로 존재하는 다당류로써 과거 D-galacturonic acid가 $\alpha-1.4$ 결합으로 연결된 고
Table 1. Chemical composition of the purified polysaccharide, RB-1b-I from Korean black raspberry wine

\begin{tabular}{lccc}
\hline Chemical property & $(\%)$ & Component sugar $^{1)}$ & $($ mole\%) \\
\hline Molecular weight & $180 \mathrm{kDa}$ & Rhamnose & 1.2 \\
& & Arabinose & 3.8 \\
Neutral sugar & 100.0 & Mannose & 76.8 \\
Uronic acid & 0.0 & Galactose & 15.8 \\
Protein & 0.0 & Glucose & 2.6 \\
\hline
\end{tabular}

${ }^{1}$ Monosaccharides were analyzed using alditol acetates. Mole $\%$ was calculated from the detected total carbohydrate.

분자 물질( $\alpha$-D-1,4-polygalacturonic acid)로만 구성되어 있다고 알 려져 왔으나, 실제로 자연계에 존재하는 펙틴은 이보다 훨씬 복 잡한 구조를 가지고 있다고 보고되어 있다(26,27). 펙틴은 전체분 자의 많은 부분은 homogalacturonan으로 구성되어 있지만(28), 여 기에 다양한 oligo- 및 polysaccharide로 분지된 rhamnogalacturonan-I(RG-1) 및 rhamnogalacturonan-II(RG-II)가 공유적으로 결합 되어 있는 것으로 알려져 있다(26,27). 이들 중 RG-I은 rhamnogalacturonan 주쇄(main chain)에 arabinan, galactan 및 arabinogalac$\tan$ 과 같은 다양한 중성 곁사슬(side chain)을 갖는 다당(29)으로 보고되어 있다. 따라서 RB-1b-I에서 mannose외에 galactose와 arabinose가 검출된 사실은 복분자주의 원재료인 복분자 중에 존재 하는 pectin이 발효과정 중 분해되어 그 side chain이 복분자주 중 용해된 형태로 존재함을 강력히 시사하였다. 따라서 RB-1b-I는 발효과정 중 발효제인 효모의 세포벽 기원의 mannan계 다당이 주를 이루며 재료인 복분자에서 유래한 arabinogalactan이 일부 함 유되어 있는 것으로 추정된다.

\section{복분자주 유래 다당의 비장세포 mitogen 활성}

비장(spleen)은 혈액으로부터 항원을 수집하며, $\mathrm{B}$ 및 $\mathrm{T}$ 림프 구의 성숙과 항원에 의해 자극을 받은 후에 림프구의 분화가 이 루어지는 주요 림프기관으로 비장 내 림프구의 증식은 면역시 스템에서 매우 중요한 의미를 갖는다(30). 복분자주 유래 다당 의 비장세포 내 임파구에 대한 mitogen 활성을 측정한 결과, Table 2에 나타난 바와 같이 복분자주 유래 조다당인 RB-0의 경 우, $100 \mu \mathrm{g} / \mathrm{mL}$ 의 농도에서 임파구 증식활성은 immune modulator 인 LPS에 비해 낮았지만, 무첨가 대조군에 비해 $260 \%$ 활성을 보였다. 고분자 정제 다당 RB-1b-I는 조다당 RB-0 보다 우수한 $307 \%$ 의 높은 활성을 보였다. 따라서 복분자주 유래 다당은 인

Table 2. Immuno-stimulating activities of the purified polysaccharide, RB-1b-I from Korean black raspberry wine

\begin{tabular}{|c|c|c|c|c|c|}
\hline \multirow{2}{*}{ Immuno-stimulating activity } & \multirow{2}{*}{$\begin{array}{l}\text { Concentration } \\
(\mu \mathrm{g} / \mathrm{mL}) \\
\text { or } \mathrm{E} / \mathrm{T} \text { ratio }\end{array}$} & \multicolumn{2}{|c|}{ Control } & \multicolumn{2}{|c|}{$\begin{array}{l}\text { Polysaccharide from Korean } \\
\text { black raspberry wine }\end{array}$} \\
\hline & & Saline & LPS $^{4)}$ & RB-0 & RB-1b-I \\
\hline \multirow{2}{*}{$\begin{array}{l}\text { Spenocyte mitogenic activity } \\
\text { (CCK-8 assay, \%) }\end{array}$} & 10 & $100 \pm 0.1^{3)}$ & $354 \pm 13.4^{*}$ & $190 \pm 9.8^{*}$ & $246 \pm 16.1^{*}$ \\
\hline & 100 & & & $260 \pm 11.0^{*}$ & $307 \pm 14.4^{*}$ \\
\hline \multirow{2}{*}{$\begin{array}{c}\text { Macrophage activity } \\
\text { (Lysosomal phosphatase, \%) }\end{array}$} & 10 & $100 \pm 1.4$ & $142 \pm 6.3^{*}$ & $133 \pm 5.3^{*}$ & $125 \pm 4.5^{*}$ \\
\hline & 100 & & & $153 \pm 3.8^{*}$ & $130 \pm 0.3^{*}$ \\
\hline \multirow{4}{*}{$\begin{array}{l}\text { NK cell-mediated tumor cytotoxicity } \\
(\text { LDH assay, } \% \text { at } 200 \mu \mathrm{g} / \text { mouse })^{1)}\end{array}$} & 100:1 & $16.5 \pm 2.9$ & & & $38.2 \pm 8.1^{*}$ \\
\hline & $50: 1$ & $14.2 \pm 4.2$ & & & $25.5 \pm 4.4^{*}$ \\
\hline & $25: 1$ & $9.8 \pm 3.4$ & & & $11.3 \pm 3.9$ \\
\hline & $12.5: 1$ & $7.25 \pm 4.0$ & & & $10.9 \pm 2.8$ \\
\hline
\end{tabular}

1) Three mice per group were administered i.v. with $200 \mu \mathrm{g}$ of sample. NK cell activity was determined as described in Materials and Methods. ${ }^{2)} \mathrm{E} / \mathrm{T}$ ratio, effector-to-target cell ratio. ${ }^{3)}$ The data were expressed as means $\pm \mathrm{SD}$ of triplicate cultures. ${ }^{4)} \mathrm{LPS}$, lipopolysaccharides from Escherichia coli O127:B8 was used as a positive control. ${ }^{*} p<0.01$; Significant difference between control (saline only) and sample. 
체 내 임파구 증식에도 유용하게 작용할 가능성이 있음을 확인 할 수 있었다.

\section{복분자주 유래 다당의 macrophage 활성화능}

Macrophage는 체내로 이물질(감염성 미생물 등)이 침입하였을 때 이들을 초기에 비특이적으로 제거시키는 탐식세포로써, 세포 매개성 면역에 중요한 역할을 담당하는 면역세포로 알려져 있으 며 염증반응(inflammatory)이나 종양치사작용(tumoricidal) 등 다양 한 기능을 수행하고 있다고 보고되고 있다(31). 또한 macrophage 는 항원을 탐식, 분해(processing)하여 그 일부를 자신의 세포 표 면에 부착, 제시(presentation)함으로써 $\mathrm{T}$ 림프구에 의한 면역반응 을 유도하여 후천성 면역계가 작동할 수 있도록 해주는 effector cell로써 작용한다(32). 복분자주 유래 다당 RB-1b-I의 macrophage 의 활성을 측정한 결과, Table 2에 나타난 바와 같이 양성 대조 군 LPS와 비교하였을 때 전체적으로 다소 낮은 활성을 보였지만 무첨가 대조군에 비해 약 $130 \%$ 의 활성을 나타냈다. 복분자주에 서 분리한 조다당인 RB-0의 경우는 LPS보다도 높은 활성을 보 이는 것으로 나타났으며 정제 획분인 RB-1b-I에 비해서도 다소 높은 활성을 보였는데, 이는 정제과정 중에 제거된 RB-2가 높은 활성을 갖는데 기인할 것으로 판단되었다. 이상의 결과로부터 복 분자주 유래 다당들은 면역 기능성 식품소재 또는 biological response modifier(BRM)로의 이용 가능성이 있음을 추측할 수 있 었다.

\section{복분자주 유래 다당의 NK cell activity}

인체 내에서 활성화된 NK-cell은 광범위하게 바이러스 감염 세 포 및 종양세포에 대하여 비특이적으로 세포독성을 나타내는 작 동세포로서 $(33,34)$, 특히 암세포에 직접 작용할 수 있다는 점에서 최근 많은 연구가 진행되고 있는 면역세포이다. 복분자주 유래의 고분자 다당을 각각 mouse당 $200 \mu \mathrm{g}$ 씩 정맥주사한 후 $\mathrm{YAC}-1$ 세 포에 대한 NK-cell의 살해능을 측정한 결과, Table 2에 나타난 바 와 같이, 복분자주 유래 정제 다당인 RB- $1 \mathrm{~b}-\mathrm{I}$ 은 $\mathrm{E} / \mathrm{T}$ 비율 100:1 에서 최대의 활성이 관찰되었다. 따라서 복분자주의 고분자 정제 다당은 NK-cell의 활성인자로 작용할 가능성이 확인되었다. 이상 의 결과는 복분자주에서 정제한 주 다당 RB-1b-I이 임파구, macrophage 및 $\mathrm{NK}$ cell과 같은 면역 관련 세포에 유효하게 작용 함을 지적하였으며, 현재 RB-1b-I의 상세한 생물학적 작용 기구 가 실험 중에 있다.

\section{보체계 활성화능}

복분자주 유래 다당에 대한 보체계 활성화능을 측정한 결과, 조다당인 $\mathrm{RB}-0$ 는 $1,000 \mu \mathrm{g} / \mathrm{mL}$ 농도에서 $\mathrm{ITCH}_{50}$ 값이 약 $60 \%$ 에 이르는 매우 우수한 보체계 활성화능을 보였다(Fig. 3). 이는 보 체계의 강력한 활성인자로 알려져 있으며, 본 실험에서 양성대조 군으로 사용한 구름버섯(Coriolus versicolor, 운지) 기원의 $\operatorname{PSK}(35)$ 와 유사한 활성이었다. 또한 이들의 활성은 $500 \mu \mathrm{g} / \mathrm{mL}$ 농도에서 $1,000 \mu \mathrm{g} / \mathrm{mL}$ 보다 높은 약 $80 \%$ 의 활성을 나타냈다. 그러나 RB0 에서 정제된 고분자 다당인 RB- $1 \mathrm{~b}-\mathrm{I}$ 은 농도의존적인 활성의 경 향을 보였으며 $1,000 \mu \mathrm{g} / \mathrm{mL}$ 농도에서 PSK보다 우수한 약 $80 \%$ 의 활성을 보였다. 정제 저분자 다당인 $\mathrm{RB}-2$ 는 각 농도에서 모두 $20 \%$ 이내의 낮은 활성을 보여 항보체 활성이 거의 없는 것으로 평가되었다. 따라서 복분자주 유래 다당의 항보체 활성은 주로 고분자 부분이 담당함을 확인할 수 있었으며, RB-1b-I은 보체계 의 강력한 활성인자임을 재차 확인할 수 있었다.

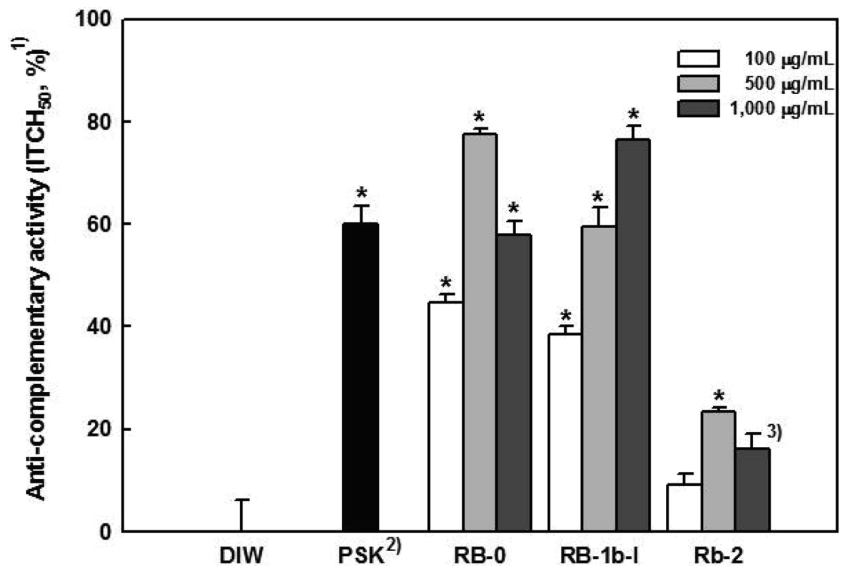

Fig. 3. Complement activation by the purified polysaccharide, RB-1b-I from Korean black raspberry wine. ${ }^{1)}$ The anticomplementary activity was expressed as the inhibition of 50\% total complement hemolysis by Mayer's method. ${ }^{2}$ PSK, a known immuno-active polysaccharide from Coriolus versicolor was used as a positive control $(1,000 \mu \mathrm{g} / \mathrm{mL}) .{ }^{3}$ The data were expressed as mean $\pm \mathrm{SD}$ of three separate experiments. ${ }^{*} p<0.01$; Significant difference between control $\left(\mathrm{H}_{2} \mathrm{O}\right.$ only) and sample.

\section{보체계 활성화 경로 검토}

보체계는 $\mathrm{C} 1-\mathrm{C} 9$ 의 활성 단백질과 조절인자를 포함하여 약 20 여종의 혈중 순환 단백질들로 구성되어 있으며, 외부감염 병원체 등 침입인자를 항체의 존재 또는 비존재 하에 비특이적으로 제 거하는 생체의 주요 방어기구이다(36). 보체계가 활성화되면 연 속적인 cascade반응에 의하여 보체 단백질이 활성 분자로 분해되 고 이들이 침입인자의 표면에 부착되어 최종적으로 $\mathrm{MAC}(\mathrm{mem}-$ brane attack complex)를 형성하여 감염 병원체 등을 제거하는 것 으로 알려져 있다(37). 또한 보체 활성화 과정 중 생성되는 여러 보체 분해산물은 각종 생리반응을 매개한다고 알려져 있으며, 특 히 macrophage와 lymphocyte의 활성화, 면역증강 등과 밀접한 상 관관계가 있다고 보고되고 있다(37). 보체계 활성화 경로는 보체 의 중요성분인 $\mathrm{C} 3$ 의 활성화 방법에 따라 보체계의 활성화 경로 는 크게 classical pathway와 alternative pathway로 구성되어 있는 데, classical pathway의 활성에는 $\mathrm{Ca}^{2+}$ 및 $\mathrm{Mg}^{2+}$ 모두, alternative pathway에는 $\mathrm{Mg}^{2+}$ 만이 선택적으로 관여하고 있는 것으로 알려져 있다(36). 따라서 활성화에 관여하는 금속이온의 존재여부에 따 라 반응계를 조절하면 보체계 활성화 경로를 예측할 수 있게 된 다. 보체계에 대해 높은 활성을 나타내었던 RB-1b-I을 대상으로 $\mathrm{GVB}^{2+}$ 기본반응계와 2가 금속이온을 모두 제거한 $\mathrm{EDTA}-\mathrm{GVB}^{2-}$ 반응계 및 $\mathrm{Ca}^{2+}$ 이온만을 선택적으로 제거한 $\mathrm{Mg}^{2+}$-EGTA-GVB ${ }^{2-}$ 반응계로 나누어 농도별로 항보체 활성 $\left(\mathrm{ITCH}_{50}\right)$ 을 비교 측정하였 다. Fig. 4에서 보는 바와 같이 복분자주 유래 활성 다당 RB-1bI의 경우, $\mathrm{Ca}^{2+}$ 및 $\mathrm{Mg}^{2+}$ 이 모두 존재하는 기본 반응계에서의 활성 과 비교할 때 2 가 금속이 모두 제거된 반응계에서는 대조군에 비 해 거의 완전한 활성의 소실이 관찰되었으나, $\mathrm{Mg}^{2+}$ 이온만 존재 하는 반응계에서는 고농도에서 활성이 상당량 유지(약 $20 \%$ 수 준)되는 결과를 보였다. 이러한 사실은 복분자주 유래 활성 다당 RB-1b-I이 보체계의 classical pathway와 alternative pathway 양 경 로를 모두 활성화시킬 수 있음을 의미하는 것으로, 특히 alternative pathway는 항체에 의한 면역 반응이 일어나기 전에 활성화되기 때문에 항원에 의해 감작되지 않은 숙주에 있어 중요한 1 차적 방 어기작이므로 그 의미가 크다고 할 수 있다(38). 


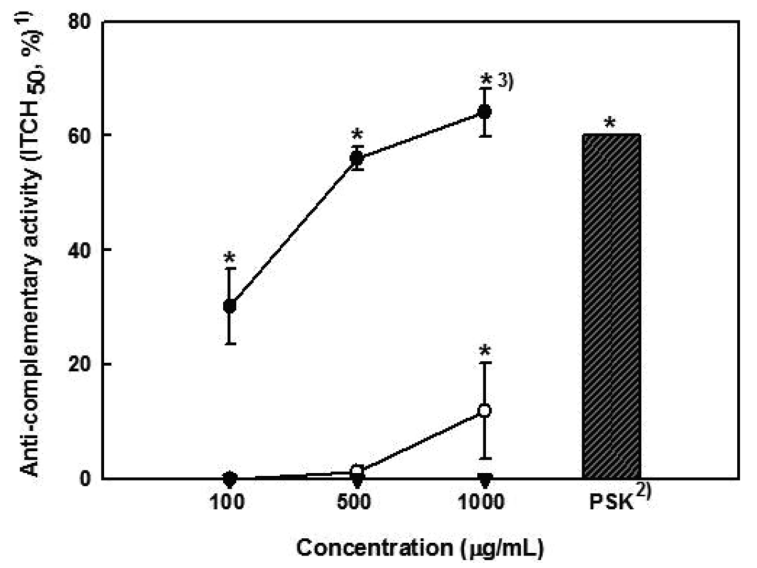

Fig. 4. Effect of calcium and magnesium ions on complement activation by the purified polysaccharide, RB-1b-I from Korean black raspberry wine. ${ }^{1)}$ The anti-complementary activity was expressed as the inhibition of $50 \%$ total complement hemolysis by Mayer's method. ${ }^{2} \mathrm{PSK}$, a known immuno-active polysaccharide from Coriolus versicolor was used as a positive control $(1,000 \mu \mathrm{g} /$ $\mathrm{mL}) .{ }^{3)}$ The data were expressed as mean $\pm \mathrm{SD}$ of three separate experiments. $\bigcirc$, in $\mathrm{GVB}^{2+} ; \bigcirc$, in $\mathrm{Mg}^{2+}$-EGTA-GVB ${ }^{2-} ; \boldsymbol{\nabla}$, in $\mathrm{EDTA}^{-G V B}{ }^{2-}{ }^{*} p<0.01$; Significant difference between control $\left(\mathrm{H}_{2} \mathrm{O}\right.$ only) and sample.

\section{2차원 면역전기영동에 의한 C3산물의 동정}

Mayer법(23)에 의한 항보체 활성측정법은 1 차 반응단계에서 시 료성분의 보체계 활성화에 의한 보체의 소모 정도를 측정하는 방 법으로 만일 시료 중 보체의 활성화가 아닌 특정한 저해성분이 존재할 경우에도 높은 항보체 활성을 보일 수 있는 문제점을 갖 고 있다(39). 따라서 RB-1b-I의 항보체 활성이 보체계 활성화에 기인한 것인지, 혹은 시료의 보체 저해활성에 의한 것인지를 확 인하기 위하여 보체계 활성화에서 가장 중요한 성분으로 알려진 $\mathrm{C} 3$ 의 활성화 여부를 조사하였다. 일반적으로 보체계가 활성화되 면 $\mathrm{C} 3$ 는 $\mathrm{C} 3 \mathrm{a}$ 와 $\mathrm{C} 3 \mathrm{~b}$ 로 분해되므로(38) 시료와 정상인 혈청을 반 응시킨 후 1 차 전기영동을 실시하고 anti-human $\mathrm{C} 3$ 를 이용하여 2 차 면역전기영동을 행함으로써 $\mathrm{C} 3$ 분해산물을 동정하고자 하였 다. Fig. 5(A)에 나타난 바와 같이 복분자주 유래 RB-1b-I와 혈청 을 기본반응계에서 반응시킨 경우는 $\mathrm{C} 3$ 의 활성화가 일어나 두 개의 침강선이 형성된 것을 관찰할 수 있었다. 따라서 RB-1b-I의 항보체 활성은 보체계의 저해가 아닌 직접 활성화에 기인함을 확 인할 수 있었다.

RB-1b-I을 $\mathrm{Mg}^{2+}$-EGTA-GVB ${ }^{2-}$ 및 EDTA-GVB ${ }^{2-}$ 반응계에서 반 응시킨 후 그 분해 산물을 관찰한 결과는 Fig. 5(B) 및 Fig. 5(C) 항에 나타난 바와 같다. 금속이온을 모두 제거한 $\mathrm{EDTA}_{-} \mathrm{GVB}^{2-}$ 반응계에서는 $\mathrm{C} 3$ 의 활성화가 진행되지 않아 1 개의 침강선이 관 찰된 반면, $\mathrm{Ca}^{2+}$ 이온을 선택적으로 제거한 $\mathrm{Mg}^{2+}$-EGTA-GVB ${ }^{2-}$ 반 응계에서는 2 개의 침강선이 관찰되었다. 교차 면역전기영동의 결 과에서 well(Fig. 5의 사진에서 우측방향)로부터 첫번째 침강선은 $\mathrm{C} 3$ 를, 두번째 침강선은 활성화된 $\mathrm{C} 3 \mathrm{a}$ 와 $\mathrm{C} 3 \mathrm{~b}$ 의 혼합물에 기인한 침강선(40)임을 고려해 볼 때, 기본 반응계인 $\mathrm{GVB}^{2+}$ 에서는 첫 번 째 침강선이 상대적으로 불분명하고 두 번째 침강선이 뚜렷한 반 면(Fig. 5(A)), $\mathrm{Ca}^{2+}$ 을 선택적으로 제거한 반응계에서는 첫 번째 침강선이 분명하게 남아있는 것으로 나타남으로써(Fig. 6(B)) 기 본 반응계에서 보체의 활성화가 훨씬 강력하게 진행되었음을 확 인할 수 있었다. 참고로 전혀 활성화가 진행되지 않은 경우(EDTA$\mathrm{GVB}^{2-}$ )에서는 Fig. $5(\mathrm{C})$ 처럼 well로부터 첫 번째 침강선만이 관

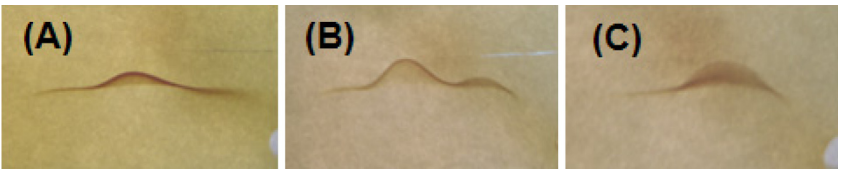

Fig. 5. Crossed immunoelectrophoretic patterns of C3 converted by the purified polysaccharide, RB-1b-I from Korean black raspberry wine. Normal human serum was incubated with the samples in $\mathrm{GVB}^{2+}(\mathrm{A}), \mathrm{Mg}^{2+}$-EGTA-GVB ${ }^{2-}$ (B) and EDTA-GVB ${ }^{2-}$ (C) at $37^{\circ} \mathrm{C}$ for $30 \mathrm{~min}$. The sera were then subjected to immunoelectrophoresis using anti-human $\mathrm{C} 3$ antibody to locate C3 cleavage products. The anode is to the left.

찰된다. 따라서 RB-1b-I은 보체계의 classical pathway와 alternative pathway의 두 경로를 모두 활성화시킴을 재차 확인할 수 있었다.

이상의 결과로부터 복분자 중 존재하는 다당은 macrophage, 임 파구 및 $\mathrm{NK}$ cell등 면역 관련 세포의 활성인자로 작용할 수 있 으며, 특히 강력한 보체 활성능을 가지고 있음이 확인되었다. 이 들은 주로 발효제인 효모의 세포벽 성분이 발효와 숙성과정 중 분해되어 선택적으로 용해된 것으로 추정되며, 이들 다당이 복분 자주의 생리활성에 중요한 역할을 담당하고 있음을 확인할 수 있 었다. 이러한 사실은 전통발효음료의 우수성을 홍보하는데 중요 하게 활용될 수 있으리라 판단된다.

\section{요 약}

한국 전통발효음료 중에 존재하는 특이 다당류의 화학적 특성 및 생물활성을 규명할 목적으로, 농가에서 직접 발효한 복분자주 로부터 다당류를 분리하고 이들의 각종 면역증강활성에 대해 검 토하였다. 복분자주에 $80 \%$ ethanol 침전을 행하여 얻어진 조다당 획분 RB- 0 를 이용, 연속적인 3 회의 column chromatography를 행 하여, 복분자주의 주요 다당인 RB-1b-I으로 정제할 수 있었다. RB-1b-I획분은 HPLC상에서 대칭을 유지하는 단일 peak로 검출 되었으며, 분자량은 약 $180 \mathrm{kDa}$ 으로 평가되었다. 정제다당인 RB$\mathrm{lb}-\mathrm{I}$ 의 구성당 조성을 확인한 결과, mannose가 $76.8 \%$ 로 주를 이 루고 있었으며, 그 외에 galactose $(15.8 \%)$, arabinose $(3.8 \%)$, glu$\operatorname{cose}(2.6 \%)$ 및 rhamnose $(1.2 \%)$ 의 순으로 함유되어 있었다. 이러한 결과는 복분자 중에 존재하는 주 다당이 발효 효모의 세포벽에 서 기원한 mannan임을 추정하게 하였다. 한편 복분자주에서 정 제한 다당 RB-1b-I은 in vitro상에서 macrophage의 활성화를 높은 비율로 유도하였으며, 비장세포에 대해 높은 증식능을 보였다. 또 한 RB-1b-I을 정맥 투여한 경우, NK cell을 활성화하여 YAC-1 종양세포에 대한 세포독성을 증가시킴이 관찰되었다. 한편 고분 자 정제 다당인 RV-1b-I은 비특이적 면역계에 있어 중요 역할을 담당하고 있는 보체계에 대하여 농도 의존적인 활성화 경항을 보 였다. 이들은 $\mathrm{Ca}^{++}$이온이 제거된 상태에서의 항보체 활성과 antihuman $\mathrm{C} 3$ 를 이용한 2차원 면역전기영동에 의하여 C3 산물을 동 정한 결과로부터 보체계의 classical pathway와 alternative pathway 양 경로를 모두 경유하여 활성을 나타냄을 확인할 수 있었다. 이 상의 결과로부터 복분자주에는 인체 건강에 유익한 면역증진 활 성을 제공하는 다당류가 함유되어 있음을 알 수 있었다.

\section{감사의 글}

본 연구는 20011학년도 경기대학교 학술연구비(일반연구과제) 지원에 의하여 수행되었음. 


\section{문 헌}

1. Wollin SD, Jones PJH. Alcohol, red wine, and cardiovascular disease. J. Nutr. 131: 1401-1404 (2001)

2. Estruch R. Wine and cardiovascular disease. Food Res. Int. 33: 219-226 (2000)

3. Kerry NL, Abbey M. Red wine and fractionated phenolic compounds prepared from red wine inhibit low density lipoprotein oxidation in vitro. Atherosclerosis 135: 93-102 (1997)

4. Tedesco I, Russo M, Russo P, Iacomino G, Russo GL, Carraturo A, Faruolo C, Moio L, Palumbo R. Antioxidant effect of red wine polyphenols on red blood cells. J. Nutr. Biochem. 11: 114$119(2000)$

5. Whitehead TP, Robinson D, Allaway S, Syms J, Hale A. Effect of red wine ingestion on the antioxidant capacity of serum. Clin. Chem. 41: 32-35 (1995)

6. Fuhrman B, Lavy A, Aviram M. Consumption of red wine with meals reduces the susceptibility of human plasma and low-density lipoprotein to lipid peroxidation. Am. J. Clin. Nutr. 61: 549-554 (1995)

7. Hager A, Howard LR, Prior RL, Brownmiller C. Processing and storage effects on monomeric anthocyanins, percent polymeric color, and antioxidant capacity of processed black raspberry products. J. Food Sci. 73: 134-140 (2008)

8. Seeram NP. Berry fruits: Compositional elements, biochemical activities, and the impact of their intake on human health, performance, and disease. J. Agr. Food Chem. 56: 627-629 (2008)

9. Tulio AZ Jr, Reese RN, Wyzogoski FJ, Rinaldi PL, Fu R, Scheerens JC, Miller AR. Cyanidin 3-rutinoside and cyanidin 3-xylosylrutinoside as primary phenolic antioxidants in black raspberry. J. Agr. Food Chem. 56: 1880-1888 (2008)

10. Wang SY, Lin HS. Antioxidant activity in fruits and leaves of blackberry, raspberry, and strawberry varies with cultivar and developmental stage. J. Agr. Food Chem. 48: 140-146 (2000)

11. Wang SY, Jiao H. Scavenging capacity of berry crops on superoxide radicals, hydrogen peroxide, hydroxyl radicals, and singlet oxygen. J. Agr. Food Chem. 48: 5677-5684 (2000)

12. Seeram NP, Adams LS, Zhang Y, Lee R, Sand D, Scheuller HS, Heber D. Blackberry, black raspberry, blueberry, cranberry, red raspberry, and strawberry extracts inhibit growth and stimulated apoptosis of human cancer cells in vitro. J. Agr. Food Chem. 54: 9329-9339 (2006)

13. Chen T, Hwang HJ, Rose ME, Nines RG, Stoner GD. Chemopreventive properties of black raspberries in $N$-nitrosomethylbenzylamine-induced rat esophageal tumorigenesis: Down-regulation of cyclooxygenase-2, inducible nitric oxide synthase, and c-Jun. Cancer Res. 66: 2853-2859 (2006)

14. Jung JW, Son MY, Jung SW, Nam PW, Sung JS, Lee SJ, Lee KG. Antioxidant properties of Korean black raspberry wines and their apoptotic effects on cancer cells. J. Sci. Food Agr. 89: 970977 (2009)

15. Lee SJ, Ahn B. Changes in physicochemical characteristics of black raspberry wines from different regions during fermentation. Korean J. Food Sci. Technol. 41: 662-667 (2009)

16. Cho JY, Kim SJ, Lee HJ, Kim JY, Lym IJ, Kang SK, Park KH, Moon JH. Isolation and identification of low molecular volatile compounds from ethyl acetate layer of Korean black raspberry (Rubus coreanus Miq.) wine. Korean J. Food Sci. Technol. 43: 558-563 (2011)

17. Dubois M, Gilles KA, Hamilton JK, Rebers PA, Smith F. Colorimetric method for determination of sugars and related substances. Anal. Chem. 28: 350-356 (1956)

18. Blumenkrantz N, Asboe-Hansen G. New method for quantitative determination of uronic acid. Anal. Biochem. 54: 484-489 (1973)

19. Bradford MM. A rapid and sensitive method for the quantitation of microgram quantities of protein utilizing the principle of protein-dye binding. Anal. Biochem. 72: 248-254 (1976)

20. Jones TM, Albersheim P. A gas chromatography method for the determination of aldose and uronic acid constituents of plant cell wall polysaccharide. Plant Physiol. 49: 926-936 (1972)

21. Suzuki I, Tanaka H, Kinoshita A, Oikawa S, Osawa M, Yadomae T. Effects of orally administered B-glucan on macrophage function in mice. Int. J. Immunopharmacol. 12: 675-684 (1990)

22. Miyagawa S, Hirose H, Shirakura R, Naka Y, Nakata S, Kawashima Y, Seya T, Matsumoto M, Uenaka A, Kitamura H. The mechanism of discordant xenograft rejection. Transplantation 46: 825-830 (1995)

23. Kabat EA, Mayer MM. Complement and complement fixation. pp. 133-240. In: Experimental Immunochemistry. $2^{\text {nd }}$ ed. Charles C (ed). Thomas Publisher, IL, USA (1971)

24. Shimura K, Ito H, Hibasami H. Screening of host-mediated antitumor polysaccharides by crossed immunoelectrophoresis using fresh human serum. Jpn. J. Pharmacol. 33: 403-408 (1983)

25. Klis FM, Mol P, Hellingwerf K, Brul S. Dynamics of cell wall structure in Saccharomyces cerevisiae. FEMS Microbiol. Rev. 26: 239-256 (2002)

26. Ridley BL, O'Neill MA, Mohnen D. Pectin: Structure, biosynthesis, and oligogalcturonide-related signaling. Phytochemistry 57: 929-67 (2001)

27. O'Neill M, Albersheim P, Darvill A. The pectic polysaccharides of primary cell walls. Vol. 2, pp. 415-441. In: Methods In Plant Biochemistry. Carbohydrates. Dey PM (ed). Academic, London, England (1990)

28. Ishii T. O-Acetylated oligosaccharides from pectins of potato tuber cell walls. Plant Physiol. 113: 1265-1272 (1997)

29. Engelsen SB, Cros S, Mackie W, Perez S. A molecular builder for carbohydrates: Application to polysaccharides and complex carbohydrates. Biopolymers 39: 417-433 (1996)

30. Male D, Brostoff J, Roth DB, Roitt I. Cells, tissues, and organs of the immune system. pp. 19-58. In: Immunology. 7th ed. Mosby, St. Louis, MO, USA (2006)

31. Keller R, Keist R, Wechsler A, Leist TP, van der Meide PH. Mechanism of macrophage-mediated tumor cell killing: A comparative analysis of the roles of reactive nitrogen intermediates and tumor necrosis factor. Int. J. Cancer 46: 682-686 (1990)

32. Nathan CF, Murray HW, Cohen ZA. Current concepts: The macrophage as an effector cell. New Engl. J. Med. 303: 662-665 (1980)

33. Shida K, Suzuki T, Kiyoshima-Shibata J, Shimada S, Nanno M. Essential roles of monocytes in stimulating human peripheral blood mononuclear cells with Lactobacillus casei to produce cytokines and augment natural killer cell activity. Clin. Vaccine Immunol. 13: 997-1003 (2006)

34. Hunter CA, Chizzonite R, Remington JS. IL-1 beta is required for IL-12 to induce production of IFN-gamma by NK cells. A role for IL-1 beta in the T cell-independent mechanism of resistance against intracellular pathogens. J. Immunol. 155: 4347-4354 (1995)

35. Saito H, Tomioka H, Sato K. PSK, a polysaccharide from Coriolus versicolor, enhances oxygen metabolism of murine peritoneal macrophages and the host resistance to listerial infection. J. Gen. Microbiol. 134: 1029-1035 (1988)

36. Kwon MH, Sung HJ. Characteristics of immune response by polysaccharides with complement system activity. Food Sci. Indus. 30: 30-43 (1997)

37. Jung YJ, Chun H, Kim KI, An JH, Shin DH, Hong BS, Cho HY, Yang HC. Purified polysaccharide activating the complement system from leaves of Diospyos kaki L. Korean J. Food Sci. Technol. 34: 879-884 (2002)

38. Whaley K. The complement system. pp. 1-35. In: Complement in Health and Disease. Whaley K (ed). MTP Press, Lancaster, PA, USA (1986)

39. Kim JH, Shin KS, Lee H. Characterization and action mode of anti-complementary substance prepared from Lactobacillus plantarum. Korean J. Food Sci. Technol. 34: 290-295 (2002)

40. Hudson L, Hay FC. Two dimensional or crossed immunoelectrophoresis. pp. 244-246. In: Practical Immunology. Blackwell Scientific Publications, Oxford, England (1989) 